\title{
Republic of Slovenia: Financial System Stability Assessment Update, including Reports on the Observance of Standards and Codes on the following topics: Banking Supervision and Insurance Supervision
}

This update to the Financial System Stability Assessment on the Republic of Slovenia was prepared by a staff team of the International Monetary Fund and the World Bank as background documentation for the periodic consultation with the member country. It is based on the information available at the time it was completed on April 23, 2004. The views expressed in this document are those of the staff team and do not necessarily reflect the views of the government of the Republic of Slovenia or the Executive Board of the IMF.

The policy of publication of staff reports and other documents by the IMF allows for the deletion of market-sensitive information.

To assist the IMF in evaluating the publication policy, reader comments are invited and may be sent by e-mail to publicationpolicy@imf.org.

Copies of this report are available to the public from

International Monetary Fund • Publication Services

700 19th Street, N.W. • Washington, D.C. 20431

Telephone: (202) 6237430 • Telefax: (202) 6237201

E-mail: publications@imf.org • Internet: http://www.imf.org

Price: $\$ 15.00$ a copy

\section{International Monetary Fund \\ Washington, D.C.}




\title{
INTERNATIONAL MONETARY FUND
}

\author{
REPUBLIC OF SLOVENIA
}

\section{Financial System Stability Assessment Update}

\author{
Prepared by the Monetary and Financial Systems and European Departments
}

\author{
Approved by Stefan Ingves and Michael Deppler
}

April 23, 2004

This Financial System Stability Assessment (FSSA) Update reports the main finding and conclusions of a joint IMF/World Bank mission to the Republic of Slovenia from November 10-21, 2003, as part of the Financial Sector Assessment Program (FSAP). It was requested by the authorities to help strengthen their oversight of the financial system in the face of new risks and competitive pressures on the system arising from EU accession and preparations to join EMU. The mission received excellent cooperation and support from the authorities.

- The mission was comprised of Hormoz Aghdaey (Mission Chief, World Bank), R. Sean Craig (Deputy Mission Chief, IMF); Alexandre Chailloux (Bank of France/IMF expert), Marcel Maes (formerly Belgium Banking and Finance Commission/IMF expert), Alexandra Gross, Joaquin Gutierrez, Olivier Hassler, Rodney Lester, and Susan Rutledge (all World Bank).

- This update, like the 2001 FSAP, finds that the Slovenian financial system appears sound overall but that it faces new challenges and risks with EU accession and entry into the new Exchange Rate Mechanism (ERM2) next year. These include increased competitive pressures on Slovenian banks from EU banks, and the risk to bank asset quality from rapid credit growth triggered by very low real interest rates associated with interest rate convergence in ERM2.

- The recommendation in the 2001 FSAP to develop a monetary policy liquidity management framework that relies more on markets was only partially implemented, although recently the authorities have taken steps to strengthen the financial market infrastructure. This framework should prove effective in limiting risks to exchange rate stability in ERM2 but by lessening incentives for the banking system to restructure, it has increased the scale of the likely restructuring necessary to make the system competitive within the EU.

- These banking sector vulnerabilities must be addressed primarily by supervision. Banking supervision registered a high degree of compliance with the Basel core principles, however, the rapid change and complexity of the financial system may necessitate a higher standard of supervision. Supervisors need to be more proactive in ensuring banks upgrade their risk assessment skills and that the pricing of risk and provisioning are appropriate. Consideration should be given to how prudential tools, such as provisioning policies, could be used to address the different sources of risk.

- Supervision of connected lending and financial conglomerates has improved, as recommended in the 2001 FSAP. However, with the likely creation of several conglomerates, consolidated supervision still needs strengthening. Partly for this reason, the authorities considered creating an integrated supervisor but have decided not to proceed at this time. This can be a successful model but there are a number of preconditions to assure this, including the need to have in place a risk-focused approach across all areas of supervision to capture synergies and careful planning to avoid disruptions. The authorities have prepared an action plan to implement FSAP-Update recommendations.

The main author of the report was R. Sean Craig.

FSAPs are designed to assess the stability of the financial system as a whole and not that of individual institutions. They have been developed to help countries identify and remedy weaknesses in their financial sector structure, thereby enhancing their resilience to macroeconomic shocks and cross-border contagion. FSAPs do not cover risks that are specific to individual institutions such as asset quality, operational or legal risks, or fraud. 
Contents

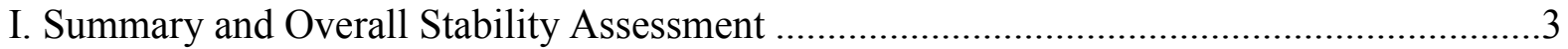

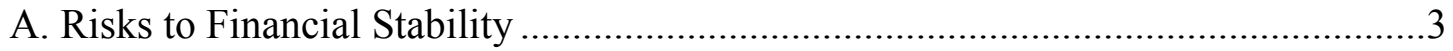

B. Strengthening Supervision of the Financial System .......................................

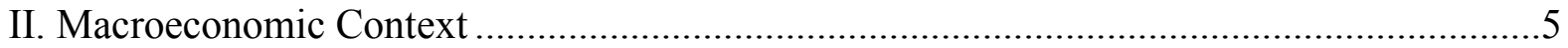

III. Monetary Policy and Liquidity Management ........................................................

IV. Macro-Prudential Analysis of the Financial System ..............................................

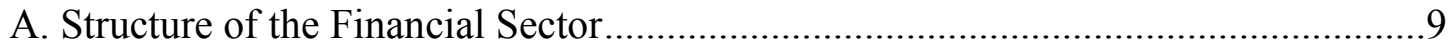

B. Soundness of the Banking Sector.............................................................. 11

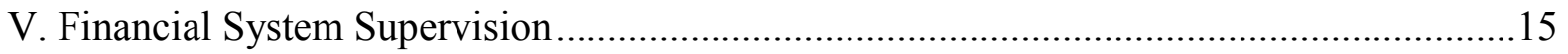

VI. Summary of Key Recommendations to Address Vulnerabilities ..................................16

Tables

1. Structure of the Bank of Slovenia Balance Sheet ...........................................................

2. Financial Soundness Indicators, 2000-03 (In percent) ................................................. 10

3. Financial Soundness Indicators for all Banks in Slovenia............................................12

4. Currency Exposure and Performance of Industrial Sectors in Slovenia............................13

5. Impact of Stress Test Shocks on Banking Sector Capital Adequacy Ratio (CAR) .............14

Figures

1. Trends in Net Interest Margin and Staff and Operating Costs.......................................

2. Net Interest Margin to Assets for Banking Systems in EU Countries ...............................8

3. Ratio of Expenses to Assets for Banking Systems in EU Countries ................................12

Boxes

1. Operation of the Slovenian Exchange Rate Regime....................................................6

Appendices

I. Implementation of Recommendations from the 2001 FSAP ........................................ 18

II. Summary Assessments of Observance of Financial Sector Standards and Codes:............19

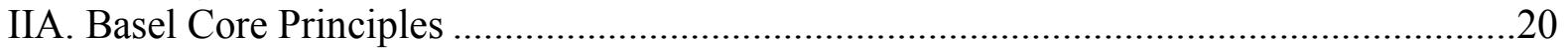

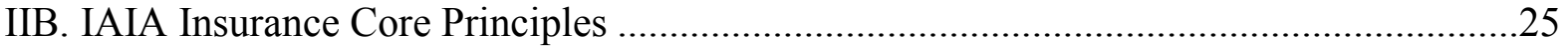




\section{Summary AND OVerall Stability ASSESSMENT}

1. The Slovenian financial system appears sound overall but faces increased competitive pressures with accession to the European Union (EU). This could lead to substantial further restructuring of the system that needs to be managed so that the process does not contribute to systemic risk. It has become more complex with the formation of financial conglomerates, which has contributed to new sources of risk and placed new demands on supervision.

2. Slovenia also faces new policy challenges and risks as it prepares to enter the new Exchange Rate Mechanism (ERM2) by early 2005 and Economic and Monetary Union (EMU) two years later. Since the 2001 FSAP, monetary policy has successfully managed the transition to a low inflation environment using a crawling band exchange rate regime but now must adapt monetary policy to ERM2. Slovenia is now well positioned to meet the Maastricht criteria for EMU but will need to focus policy on ensuring inflation and interest rate convergence, and exchange rate stability in ERM2.

\section{A. Risks to Financial Stability}

3. Interest rate convergence in the transition to EMU could contribute to several macroeconomic risks. Real interest rates could fall to low levels as nominal interest rates decline more rapidly that inflation, stimulating demand for credit. An associated shift in bank portfolios, possibly together with large capital inflows, could fuel rapid loan growth. Loan growth has recently accelerated, especially loans denominated in euros. This could contribute to inflationary pressures and a deterioration in bank credit quality as banks make riskier loans. The latter, together with a compression of interest margins, could make the banking sector more vulnerable.

4. The current monetary policy framework should effectively limit risks to exchange rate stability in ERM2. However, by lessening incentives for the banking system to restructure, it has increased the scale of the likely restructuring necessary to make the system competitive within the EU, contributing to risks that will need to be managed. Specifically, the relatively high yields on BoS bills have supported earnings of weaker banks, but these have fallen and are likely to decline further with interest rate convergence in ERM2. Also, the framework reduced incentives to develop market risk management and operations capacity and as banks strengthen this capacity smaller banks will be at a disadvantage.

5. The Bank of Slovenia (BoS) should continue steps to enhance the role of markets in the financial system, especially repo markets. This could include some limited market intervention by the BoS, as long as this does not pose any risk of exchange rate instability. Since it will use repos as a Eurosystem national central bank with EMU, the BoS may want to develop this capacity beforehand. The development of a market infrastructure is likely to contribute to the competitiveness of the banking system. 
6. Banking sector vulnerability to macroeconomic risks was assessed using stress tests. These included an exchange rate depreciation, a narrowing of the banks' interest rate margins, and a worsening of the credit quality of banks' loan portfolios. The narrowing of margins to the EU average pushes the banking system into loss, indicating a need to strengthen competitiveness. However, another stress test showed that much of this effect could be offset if banks also reduce operating costs to the EU average. The deterioration in credit quality raises nonperforming loans (NPLs) by roughly 50 percent and pushes the average capital adequacy ratio below 8 percent. This highlights the importance to financial stability of ensuring banks have adequate credit assessment capabilities and provisioning policies.

\section{B. Strengthening Supervision of the Financial System}

7. The vulnerabilities identified above must be addressed primarily by supervision, which needs to:

- $\quad$ Limit the adverse effects on banking system soundness of increased competitive pressures and interest rate spread compression by closely monitoring bank profitability, credit risk and loan pricing, and be prepared to take prompt action to resolve weak banks;

- $\quad$ Limit risks from an acceleration of credit growth, by evaluating banks' credit risk management and loan pricing and, if they appear inadequate, consider scope for using prudential tools to address this source of risk; and

- Monitor banks' indirect credit risk arising from the foreign currency exposure of the corporate sector and ensure that banks adequately take it into account in their lending and loan pricing decisions.

8. Banking supervision registered a high level of compliance with the Basel Core Principles. However, the rapid change and increasing complexity of the financial system may necessitate a higher standard of supervision with a stronger risk focus. To address the above vulnerabilities, supervisors will need to be more proactive by ensuring banks upgrade their risk assessment skills and that the pricing of risk and provisioning are appropriate. To meet these and other demands (e.g., AML/CFT), supervisory resources will have to expand.

9. The insurance sector lacks transparency and needs to develop the capacity to set pricing, provisioning and capital at appropriate levels. The limited independence of the supervisory agency needs to be addressed by reforming laws that give the supervisor more administrative and budgetary autonomy from the government and by providing supervisors with indemnity against legal action. Also, gaps in the technical skills of staff need to be addressed. Finally, there is a clear gap in the supervision of the pensions sector, which is split between the securities market and the insurance supervisors. 
10. A single regulatory agency has been proposed to replace the lead supervisor approach. While this can be a successful model for supervision, there are a number of preconditions to assure this. First, the synergies it provides derive in part from applying a risk-focused approach across all areas of supervision so it would be desirable to have this in place. Second, implementation of this model has often temporarily disrupted supervision so to limit the risk to financial stability during the transition, the financial system should not be under stress or undergoing rapid change. Given the likely stress on the system from EU accession, the authorities have decided to defer a decision on whether to move to an integrated supervisor model until conditions are more suitable. In the short term, there is a need to strengthen cooperation between the three supervisory agencies.

11. Slovenia's corporate governance legal framework is well developed and displays a high degree of transparency in disclosure of ownership and control. However, more can be done to strengthen the effectiveness of supervisory boards. International Financial Reporting Standards and relevant EU guidelines are being adopted, but the institutional arrangements to enforce the standards are not yet in place.

\section{Macroeconomic ConteXt}

12. The Slovenian economy has performed well overall. Real GDP growth, slowed to 2.3 percent in 2003 from 2.9 percent in 2002 - despite a strengthening of domestic demandowing to weak external demand. The associated widening of the output gap and favorable wage developments contributed to a decline in inflation from 7.2 percent in December 2002 to 3.6 percent in February 2004. However, with growth expected to rebound, policy may need to focus on bringing inflation below 3 percent by 2006 to meet the Maastricht inflation criteria. Fiscal policy has been, and is likely to remain, moderately restrictive. In 2003, the general government deficit was 1.4 percent of GDP, well within the 3 percent Maastricht upper limit, while government debt was 27 percent of GDP, well below the 60 percent limit.

\section{Monetary Policy And Liquidity Management}

\section{Monetary policy has focused on reducing inflation using a crawling band} exchange rate regime. Official interest rates have declined in tandem with inflation and in mid March were around 51/2 percent on 60-day Tolar Treasury bills. Since the 2001 FSAP, monetary policy has had to contend with large capital inflows, which totaled roughly 7 percent of GDP in 2002. The BoS has relied on 7-day foreign exchange swaps to absorb these inflows and Tolar central bank bills to absorb excess liquidity (Box 1). The need to sterilize these inflows has limited the scope to reform the liquidity management framework by relying more on market instruments as recommended on the 2001 FSAP. This framework proved effective but now faces new monetary policy challenges associated with ERM entry. 


\section{Box 1. Operation of the Slovenian Exchange Rate Regime}

The BoS framework for exchange rate policy operations, which is likely to be adapted to hold the exchange rate within a very narrow band inside the ERM2 band has three main features:

- $\quad$ a foreign exchange swap based on a formal contract with banks for "cooperation between bank[s] and the BoS in foreign exchange interventions;"

- $\quad$ The use of Tolar central bank bills to absorb the liquidity created by the swap; and

- $\quad$ Prudential rules that create a strong incentive for banks to participate in the swap.

The banking system has a structural long position in euros because depositors exchange euros for higher yielding local currency deposits while borrowers prefer euro loans with lower and less volatile interest rates. They need to close this long position in foreign exchange to meet the open position and liquidity ladder prudential restrictions. The effect of the swap is to transfer to the BoS banks' exchange rate risk, which is substantial given that the volume of swaps is around 10 percent of banking sector assets. The BoS then sells central bank bills to banks to absorb the Tolar liquidity created by the swaps. Since the BoS is the sole counterparty to banks in these transactions, the incentive for banks to develop wholesale interbank markets is reduced. The net cost to banks of the swap is roughly 50 basis points (the interest rate paid to the BoS exceeds the capital gain from the exchange rate depreciation, which is reflected in the different pricing of the two legs of the swap). However, the relatively high interest rate paid on BoS bills sold to banks more than offsets this cost on average. This arrangement, however, tends to slow the restructuring process by supporting the earnings of weaker banks, because the swaps are used primarily by the larger, more efficient, internationally oriented banks who receive a large share of capital inflows while the high-yielding BoS bills go disproportionately to smaller banks. Recently, the BoS has taken steps to rectify this by tying sale of higher yielding 270-day bills directly to the volume of swap transactions.

14. The transition from the current crawling band regime to ERM2 entails several risks. These arise from the likely decline in real interest rates to low levels in ERM2 as nominal interest rates converge to EU levels while inflation falls more slowly. They include:

- A sharp acceleration in economic growth sufficient to prevent inflation declining by enough to meet the Maastricht criteria during the assessment period;

- $\quad$ Rapid credit growth, perhaps supported by large capital inflows, resulting in a substantial increase in bank credit risk exposures;

- $\quad$ A further narrowing of bank interest margins (Figure 1), which could weaken bank earnings and lead them to reach for yield by taking on additional credit risk.

Contributing to these risks is the fact that monetary policy will need to focus on maintaining exchange rate stability and, thus, has less scope to respond to other sources of risk. This increases the need to rely on other macroeconomic and prudential policy tools. 
Figure 1. Trends in Net Interest Margin and Staff and Operating Costs

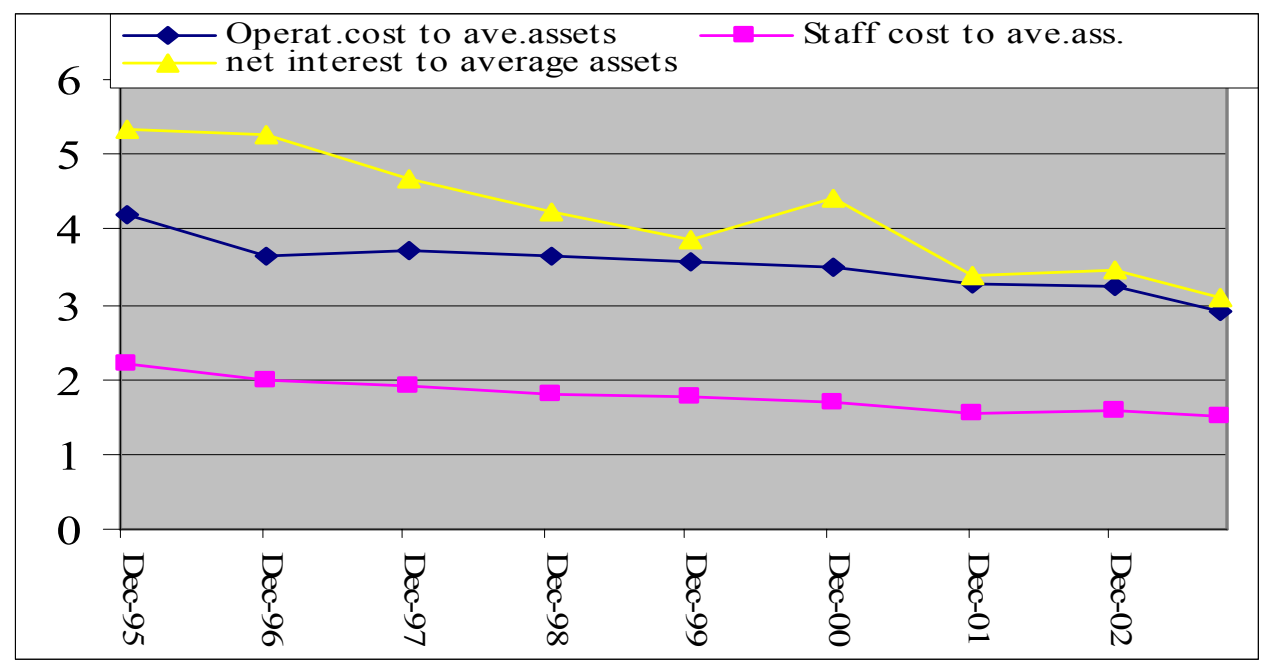

Source: OECD.

15. The monetary policy framework contributes to the vulnerability of the financial system to macroeconomic risks in ways that could continue in ERM2. Specifically:

- $\quad$ Relatively high yields on BoS central bank bills have contributed to an average interest rate spread well above that in the EU (Figure 2), which has supported the earnings of weaker banks and reduced pressures for restructuring needed to make the banking system more competitive;

- The cost of foreign exchange swaps are borne disproportionately by a few larger more internationally oriented banks who receive a large share of capital inflows, which tends to distort competition and slow the restructuring process; and

- BoS monetary operations transfer most exchange rate risk to the BoS, removing this incentive for banks to develop market risk management and operations capacity and discouraging development of wholesale markets needed for risk management.

16. These effects can be lessened through steps to develop the role of markets in monetary operations, some of which are being undertaken by the BoS. Another consideration is that upon entry into EMU the BoS will start using Eurosystem monetary instruments, so there may be advantages to developing this capacity in advance to minimize any operational risks from starting with untested instruments. This would also help banks develop the capacity to use Eurosystem money markets. The BoS has considerable flexibility regarding when, and how, to put in place the necessary market infrastructure. 
Figure 2. Net Interest Margin to Assets for Banking Systems in EU Countries

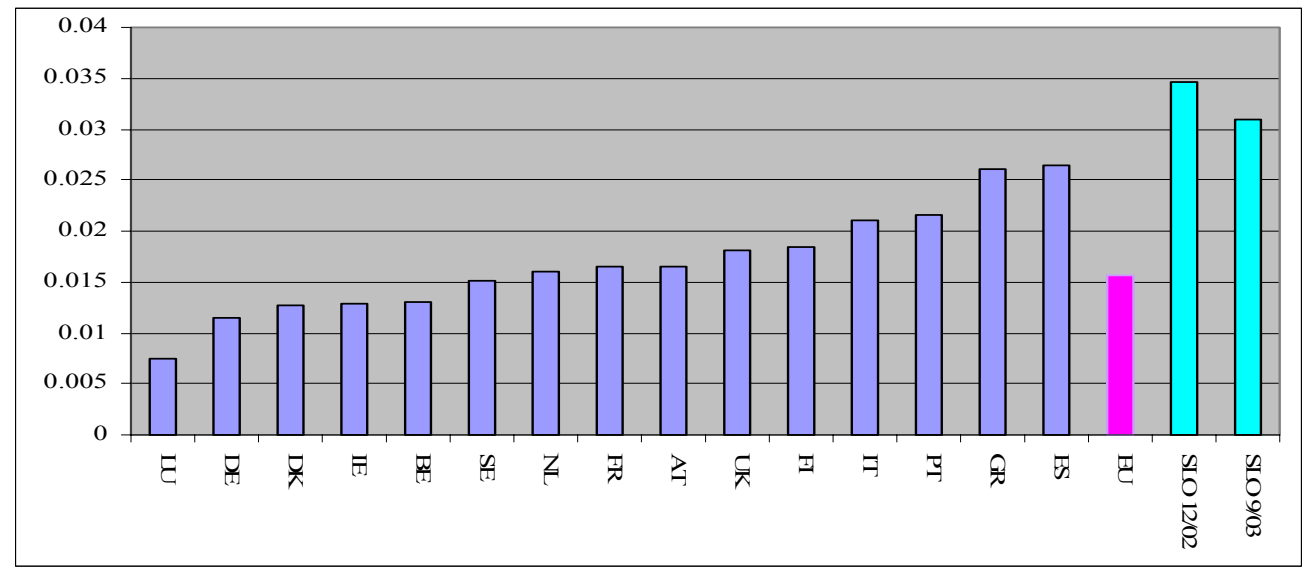

Source: OECD.

17. A key consideration in developing this infrastructure is to limit risks to exchange rate stability. The concern is that development of liquid wholesale markets would provide a vehicle for taking speculative positions against the currency. This risk could be minimized by showing strong convergence to the Maastricht criteria and through an agreement with the Eurosystem to defend the narrow band. The policy on the provision of euros by the Eurosystem to ERM2 countries to defend the ERM2 band is clear: "interventions at the margins [of the band] are in principle automatic and unlimited." However, the provision of euros for intra-marginal intervention to defend a narrower band within the ERM2 band requires a "mutual agreement" with the Eurosystem. ${ }^{1}$ The indications are that the Eurosystem will set a relatively low limit on the size of its intra-marginal intervention and will initiate it only after Slovenia's foreign currency reserves have been largely exhausted. Given that the BoS intends to hold the exchange rate within a narrow band inside the ERM2 band, it will need to proceed more cautiously in shifting to market intervention.

18. The development of market operations could proceed gradually. The BoS could continue to use existing instruments to manage overall liquidity while using market intervention at the margin on a limited scale initially. Use of variable rate auctions would encourage market pricing of foreign exchange. In particular, the foreign exchange swaps could continue to function as the main instrument for absorbing foreign exchange but at a predetermined exchange rate that could differ slightly from the market rate. In this way it could function like a standing facility fixing the edge of the fluctuation band. Similarly, to manage domestic currency liquidity and sterilize the impact of foreign exchange operations, the BoS could start to use repo as well as transactions in BoS bills.

\footnotetext{
${ }^{1}$ December 18 ECB note Policy Position of the Governing Council of the ECB on Exchange Rate Issues Relating to the Acceding Countries. Currently, only Denmark, the only country in ERM2, has such a mutual agreement Eurosystem infra-marginal intervention to support a narrow band.
} 
19. Banks would need to develop their risk management and trading capacity to participate in interbank repo and foreign exchange markets. However, bank supervisors would need to ensure that they had adequate risk management systems. To support the development of these markets the BoS could help put in place the market infrastructure including a market making capacity. This should help strengthen the competitiveness and soundness of the banking sector and prepare banks to operate in Eurosystem money markets. It could also encourage consolidation because smaller banks would be less able to achieve the economies of scale in risk management and would continue to rely on swaps.

20. The development of repo markets depends on steps to strengthen the market infrastructure, some of which are being implemented. These include a workable repo master agreement and market making arrangements for a market in Treasury bills (T-bills). The BoS lacks sufficient holdings of government securities to use for repo but can (and plans to) conduct repos using other types of securities on its balance sheet (Table 1). Also, the BoS has government securities from Euro area countries on its balance sheet as reserve assets that it could use to conduct repo operations as a Eurosystem national central bank upon entry into EMU.

Table 1. Structure of the Bank of Slovenia Balance Sheet

(Percentage of total assets in 2002)

\begin{tabular}{lr|lr}
\hline \multicolumn{1}{c|}{ Assets } & \multicolumn{2}{|c}{ Liabilities } \\
\hline Foreign Currency & 98 & Foreign currency & 37 \\
Of which: & & Of which: & \\
$\quad$ Securities: & 58 & & BoS bills \\
Domestic currency & 0.4 & Domestic currency & 33 \\
Fixed assets & 2 & Of which: & 39 \\
& & BoS Tolar bills & 23 \\
& Gov. deposits & 8 \\
& Currency & 11 \\
& Capital & 13 \\
\hline
\end{tabular}

\section{Macro-Prudential Analysis of the Financial System}

\section{A. Structure of the Financial Sector}

21. The banking sector accounts for most of the financial system making it the primary source of systemic risk. Total assets of the sector have increased substantially during the past few years and at end-2002 were about 80 percent of GDP (Table 2). The sector is highly concentrated with the largest bank accounting for around one-third, and the three largest banks around 55 percent, of sector assets. Six out the 20 banks have majority 
Table 2. Financial Soundness Indicators, 2000-03 (In percent)

\begin{tabular}{|c|c|c|c|c|c|}
\hline & 2000 & 2001 & 2002 & 2003H1 & 2003Q3 \\
\hline \multicolumn{6}{|l|}{ Capital Adequacy } \\
\hline Regulatory capital to risk-weighted assets & 13.5 & 11.9 & 11.9 & 11.6 & 11.4 \\
\hline Regulatory Tier 1 capital to risk-weighted assets & 12.6 & 11.3 & 9.9 & 9.7 & 9.6 \\
\hline Capital (net worth) to assets & 10.1 & 8.8 & 8.3 & 7.8 & 7.8 \\
\hline \multicolumn{6}{|l|}{ Assets Composition and Quality } \\
\hline Total assets (in billions of Euro) & 14.8 & 17.5 & 19.8 & 20.7 & 21.0 \\
\hline \multicolumn{6}{|l|}{ Sectoral distribution of loans (in percent of total) } \\
\hline - Nonbank financial institutions & 2.6 & 2.6 & 3.4 & 3.8 & 3.9 \\
\hline - Nonfinancial enterprises & 57.6 & 61.1 & 58.9 & 63.2 & 63.2 \\
\hline - Private households & 29.6 & 27.2 & 25.8 & 25.2 & 25.4 \\
\hline - Public sector & 9.2 & 8.3 & 9.9 & 6.3 & 5.8 \\
\hline - Nonresidents & 1.0 & 0.8 & 1.9 & 1.6 & 1.7 \\
\hline Nonperforming loans to total gross loans & 6.5 & 6.9 & 6.9 & 6.8 & 6.7 \\
\hline Nonperforming loans net provision to capital & 32.1 & 35.5 & 36.3 & 34.8 & 34.1 \\
\hline Large exposures to capital & 185.1 & 203.0 & 194.9 & 195.7 & 197.7 \\
\hline Deposits (excluding interbank) to loans & 131.9 & 144.3 & 144.3 & 138.5 & 135.8 \\
\hline Foreign currency-denominated loans to total loans & 29.4 & 29.8 & 32.6 & 33.7 & 34.9 \\
\hline Foreign currency-liabilities to total liabilities & 40.9 & 50.0 & 39.8 & 39.4 & 40.6 \\
\hline $\begin{array}{l}\text { Foreign currency-denominated loans to households } \\
\text { to total claims on households }\end{array}$ & 0.6 & 0.7 & 0.7 & 0.8 & 0.8 \\
\hline \multicolumn{6}{|l|}{ Earnings and Profitability } \\
\hline ROA & 1.1 & 0.5 & 1.1 & 1.2 & 1.2 \\
\hline ROE & 11.4 & 4.8 & 13.3 & 14.8 & 15.7 \\
\hline $\begin{array}{l}\text { Net interest margin to (operating income) average } \\
\text { interest bearing assets }\end{array}$ & 4.7 & 3.6 & 3.7 & 3.4 & 3.3 \\
\hline Operating expenses to operating income & 59.0 & 65.2 & 59.7 & 62.7 & 60.7 \\
\hline Personnel expenses to (noninterest) all expenses & 9.4 & 10.0 & 11.2 & 11.9 & 12.2 \\
\hline $\begin{array}{l}\text { Spread between average lending and deposit rates } \\
\text { (for all banking system) }\end{array}$ & 6.4 & 4.9 & 5.1 & 4.9 & 4.9 \\
\hline \multicolumn{6}{|l|}{ Liquidity } \\
\hline $\begin{array}{l}\text { (Liquid assets to total assets) Average short-term } \\
\text { assets to average short-term liabilities }\end{array}$ & 85.4 & 89.2 & 90.4 & 93.2 & 93.4 \\
\hline \multicolumn{6}{|c|}{ Market Risk } \\
\hline \multicolumn{6}{|c|}{ Duration of liabilities (in percent of total liabilities to nonbank sector) } \\
\hline - Less than 3 months & 62.8 & 62.1 & 52.9 & 52.1 & 53.9 \\
\hline - Between 3 months and 1 year & 28.5 & 30.2 & 37.6 & 37.7 & 36.8 \\
\hline - Between 1 year and 2 years & 7.7 & 6.2 & 1.1 & 1.0 & 1.1 \\
\hline - More than 2 years & 1.1 & 1.5 & 8.4 & 9.2 & 8.3 \\
\hline Net open position in foreign exchange to capital & 21.5 & 33.9 & 51.6 & 55.9 & 53.5 \\
\hline Net open position in equities to capital & 4.4 & 5.1 & 4.8 & 4.5 & 4.3 \\
\hline
\end{tabular}

Source: Bank of Slovenia. 
foreign ownership and foreigners own one-third of banking system equity. The insurance sector has grown rapidly but still accounts for only 6 percent of financial system assets.

22. State control of the banking system is still significant but its ownership of bank equity fell from 37 percent at end 2001 to around 20 percent at end 2002 . However, the government may still exert significant control over some banks and two key insurance groups through minority holdings and indirectly, for example, through pension and compensation funds. This may have slowed consolidation by making it harder for larger bank to acquire shares needed to take over small banks. In preparation for the increased competition with EU accession, the government is actively using its influence to encourage the formation of three financial conglomerates, two of which could be formed around insurance companies.

\section{Interlinkages in terms of ownership, lending and risk-sharing among the} different financial sectors may contribute to financial system vulnerabilities. One source of concern is the interlinkage between the banking and insurance sectors arising from the latter's guarantee of a large share of bank loans to households. If the insurance sector becomes unable to honor the guarantee, the credit risk on these loans in bank portfolios would rise sharply, requiring additional provisions. Another potential source of vulnerability is the guaranteed rates of return on some insurance products provided by insurance companies owned by banks.

\section{B. Soundness of the Banking Sector}

24. Financial soundness indicators show the banking sector to be sound (Table 2). Banks are well capitalized, with an average regulatory capital ratio of around $11 \frac{1 / 2}{2}$ percent. Return on equity appears good with an average of around 15 percent. However, interest margins have narrowed steadily, to around $3 \frac{1}{4}$ percentage points, putting downward pressure on earnings (Figure 2). Asset quality appears satisfactory with a reported ratio of nonperforming loans to total loans of between 6 and 7 percent. However, the ratio of operating expenses relative to assets is relatively high compared to the EU average (Figure 3), although other measures are more favorable, such as the cost to income ratio, which is closer to the EU average.

25. Lending to the nonfinancial sector is growing at a manageable pace, and in September 2003 was 10 percent above its level one year earlier. However, roughly one-third of lending to the corporate sector is in foreign exchange, contributing to a large short foreign exchange exposure that represents an indirect credit risk to banks (Table 4). This exposure varies substantially across sub sectors but tends to be large in sectors that do not export much and therefore lack a natural hedge, such as business services and electricity, gas and water sectors. In contrast, the manufacturing sector is long in foreign currency, probably due to large transaction balances held in foreign currency resulting from its high export share. 
Table 3. Financial Soundness Indicators: Slovenian-Owned Banks (Data for 2003Q3, in percent)

\begin{tabular}{lr}
\hline Capital Adequacy & 11.5 \\
Regulatory capital to risk-weighted assets & 9.6 \\
Regulatory Tier 1 capital to risk-weighted assets & 7.9 \\
Capital (net worth) to assets & \\
& 6.5 \\
Asset Quality & 35.2 \\
Nonperforming loans to total gross loans & 186.7 \\
Nonperforming loans net provision to capital & \\
Large exposures to capital & 35.3 \\
& 4.9 \\
Market Risk & \\
Net open position in foreign exchange to capital & \\
Net open position in equities to capital & \\
\hline
\end{tabular}

Source: Bank of Slovenia.

Figure 3. Ratio of Expenses to Assets for Banking Systems in EU Countries

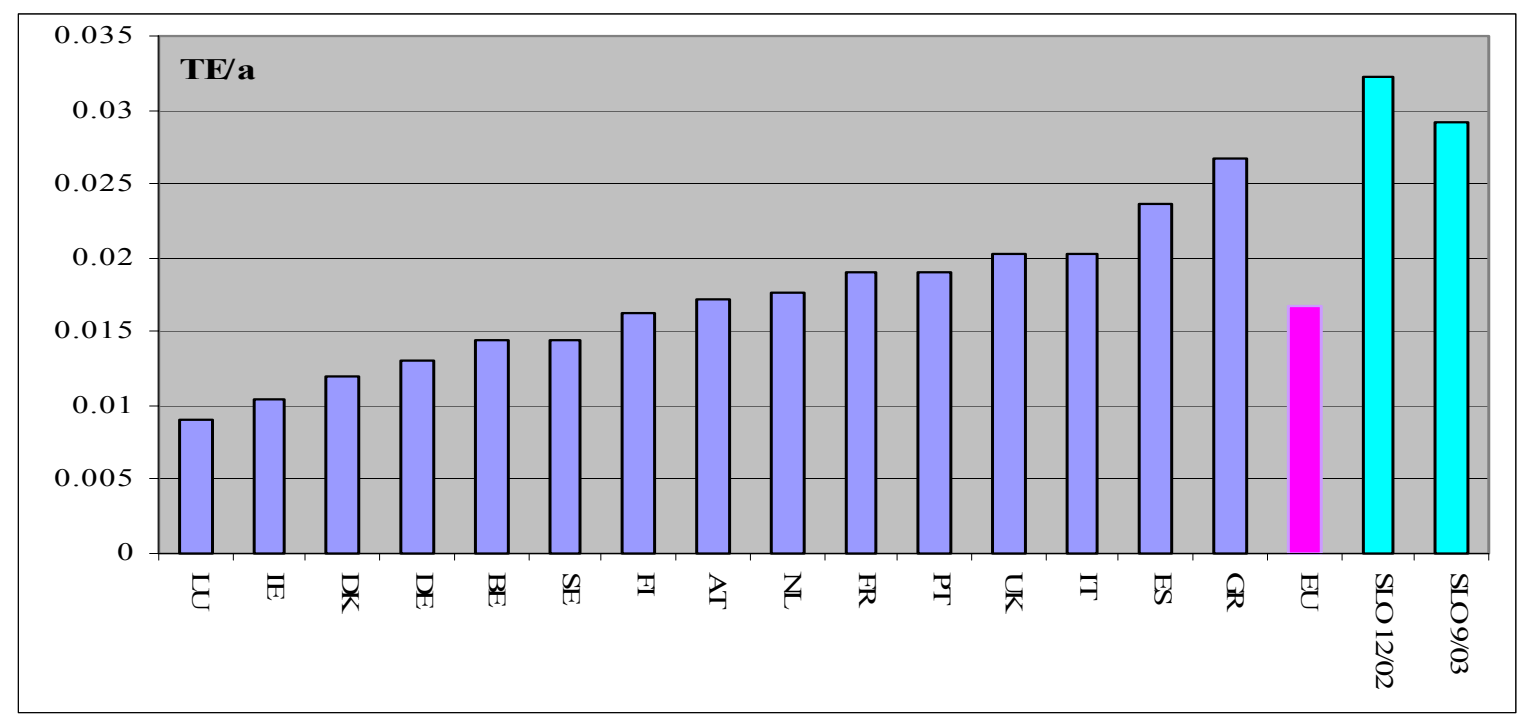

Source: OECD. 
Table 4. Currency Exposure and Performance of Industrial Sectors in Slovenia (In percent)

\begin{tabular}{lcccccc}
\hline & Open position/ & Assets & \multicolumn{2}{c}{ Export Share of Sales } & \multicolumn{2}{c}{ ROA } \\
& 2001 & 2002 & 2001 & 2002 & 2001 & 2002 \\
\hline Manufacturing & 12 & 13 & 58 & 61 & 4 & 3 \\
Electricity, gas and water & -20 & -22 & 0 & 0 & -2 & 4 \\
Construction & 4 & 0 & 3 & 6 & 0 & 1 \\
Wholesale and retail trade & -5 & -8 & 3 & 3 & 3 & 3 \\
Transport and communication & -11 & -11 & 27 & 28 & 0 & -1 \\
Business services & -26 & -14 & 0 & 0 & 11 & 9 \\
Public administration & -8 & -9 & 0 & 0 & 0 & 0 \\
\hline
\end{tabular}

Source: Bank of Slovenia calculations based on national data.

\section{The potential impact of the macroeconomic risks identified above on the} soundness of the financial system was assessed using the following stress tests:

- An exchange rate depreciation of 10 percent to the bottom of, or below, the ERM band due to exchange market pressures, possibly triggered by concerns that the Maastricht criteria might not be met;

- A substantial further narrowing of interest rate margins by 50 percent to the EU average of 1.6 percentage points from a level higher than in any EU country (Figure 2), due to competition from foreign banks and convergence of Tolar and euro interest rates;

- $\quad$ The net effect when the last scenario is accompanied by an offsetting reduction in the total expenses to assets ratio to the EU average from its current level well above that in any EU country (Figure 4);

- A deterioration in the credit quality of loan portfolios resulting from a sustained period of rapid credit growth that results in a migration of 25 percent of loans in each classification category (A, B, C, D) down into the adjacent lower category, raising the NPLs/loans ratio by 3.2 percentage points (or 45 percent);

\section{The stress tests show that the financial system is vulnerable to interest rate} spread compression and a deterioration in asset quality (Table 5). The exchange rate depreciation (stress test 1) has a very small impact. This reflects banks' very small open position largely due to prudential requirements. However, this stress test does not capture the indirect effect through the corporate sector whose foreign exchange exposure represents a source of bank credit risk (Table 4), as the data needed to incorporate this sector into the stress test are lacking. The impact of the narrowing of the interest rate margin (stress test 2) makes the banking sector as a whole unprofitable. The initial effect on the CAR is small but, if no reforms are undertaken, the cumulative effect over a number of years could be significant. However, if banks managed to cut operating costs to the EU average, this would offset much of the effect of the narrowing of the interest margin, (stress test 3 ). The decline 
in assets quality (stress test 4), which could arise from rapid credit growth and riskier lending to pick up yield as earnings fall, sharply reduces the average CAR for the system to below the 8 percent limit, with 8 banks below the limit.

28. These shocks can be combined in scenarios since their impacts are additive. One scenario is a sharp fall in bank profitability due to the narrowing of interest margins together with a deterioration in credit quality, possibly because banks start to make riskier loans to try to offset part of this narrowing of margins. Its impact is to reduce the capital ratio of domestic banks by 4.8 percentage points and is derived by combining stress tests 2 and 4 .

Table 5. Impact of Stress Test Shocks on Banking Sector Capital Adequacy Ratio (CAR)

\begin{tabular}{|c|c|c|c|c|c|c|c|}
\hline \multirow[t]{2}{*}{ Stress test shock } & \multicolumn{3}{|c|}{$\begin{array}{l}\text { Domestically owned banks } \\
\text { (percent) }\end{array}$} & \multicolumn{3}{|c|}{$\begin{array}{c}\text { Foreign bank subsidiaries } \\
\text { (percent) }\end{array}$} & \multirow{2}{*}{$\begin{array}{c}\text { Banks } \\
\text { below } \\
8 \text { percent } \\
\text { CAR }\end{array}$} \\
\hline & $\begin{array}{l}\text { Change } \\
\text { in CAR }\end{array}$ & $\begin{array}{l}\text { New } \\
\text { CAR }\end{array}$ & $\begin{array}{l}\text { change in } \\
\text { profits }\end{array}$ & $\begin{array}{l}\text { Change } \\
\text { in CAR }\end{array}$ & $\begin{array}{l}\text { New } \\
\text { CAR }\end{array}$ & $\begin{array}{l}\text { change in } \\
\text { profits }\end{array}$ & \\
\hline $\begin{array}{l}\text { 1) } 10 \text { percent currency } \\
\text { depreciation (excluding } \\
\text { swaps) }\end{array}$ & 0 & 11.8 & -3 & -0.2 & 10.5 & -68 & 0 \\
\hline $\begin{array}{l}\text { 2) } 50 \text { percent narrowing of } \\
\text { interest margin }\end{array}$ & -0.6 & 11.2 & -109 & -1.1 & 9.6 & -193 & 3 \\
\hline $\begin{array}{l}\text { 3) After reduction in } \\
\text { operating cost to EU level } \\
\text { 4) } 25 \text { percent of loans migrate }\end{array}$ & 0 & 11.8 & -22 & -0.1 & 10.6 & -23 & 1 \\
\hline $\begin{array}{l}\text { to lower rating category } \\
\text { (NPLs/loans rise } \\
45 \text { percent) }\end{array}$ & -4.2 & 7.2 & -226 & -3.9 & 7.2 & -414 & 8 \\
\hline
\end{tabular}

29. The banking sector vulnerabilities during the transition to EMU identified above need to be addressed primarily by supervisors given the constraints on monetary policy arising from ERM2. Specifically, they could:

- $\quad$ Seek to limit the adverse effects on banking system soundness as competitive pressures on banks increase with EU accession and interest rate spreads narrow by closely monitoring their profitability, credit risk and loan pricing, and be prepared to take prompt action when bank performance deteriorates in order to facilitate the orderly exit of weak banks.

- To limit risks from, and potential for, a sharp acceleration of credit growth, evaluate banks' credit risk management capabilities to assess whether they are adequate to prevent a significant deterioration in asset quality for the system as a whole and, if they appear inadequate, consider the scope for using prudential tools, including provisioning policies, to address this risk.

- Monitor banks' indirect credit risk arising from the foreign currency exposure of the corporate sector and ensure that banks adequately take this risk into account in their lending decisions and loan pricing. 


\section{FinANCIAL SYSTEM SUPERVISION}

\section{Banking supervision showed good compliance with the Basel Core Principles} and continues to improve as reflected in several upgrades from the 2001 FSAP assessment. However, with the greater complexity of the financial sector and the likely stress of EU accession, supervision could set a higher standard. Supervisors will need the capacity to assess how banks measure and quantify risks in order to foster appropriate pricing of risk and adequate provisioning. More use could be made of the credit register and corporate database to assess the credit risk arising from corporate sector weaknesses and ensure that banks provision and price risk adequately. The BoS should consider how different prudential tools could be used to address risks identified above. In this regard, the BoS is in contact with the Bank of Spain to explore the scope for adapting the dynamic provisioning model used in Spain to the Slovenian situation. ${ }^{2}$ There is also a need to intensify consolidated supervision of domestic conglomerates, including their intra-group transactions and risk transfers. This will require an increase in supervisory resources, which is strained by an expanding mandate. The banking supervision department of the BoS has drawn up an action plan to implement specific recommendations from the Basel Core Principles reassessment (in the attached ROSC). It includes plans to put in place a system for off-site monitoring of connected lending and guidelines for best practices in this area within the next few months.

31. Insurance supervision needs to address the lack of transparency regarding the financial position of the life insurance sector. It need to address the risk arising from the provision of guarantees that transfer consumer and mortgage lender's credit risk from banks to the insurance system. This requires that insurers adopt the risk management systems and international product structures to enable them to set pricing, provisioning and capital at appropriate levels. The independence of the supervisory agency is limited by laws that leave administrative and budgetary authority with the government. This, and the less than transparent nature of decision making, led to downgrades in the IAIS assessment. The technical skills of staff may be inadequate for a post EU accession environment, so a training program needs to be put in place and to this end technical assistance should be considered. The government also needs to provide responsible officers with indemnity against legal actions. In addition, there is a clear gap in the supervision of the pensions sector, which is split between the securities market and the insurance supervisory agencies.

\section{An IOSCO reassessment was not conducted, but progress with regard to} the 2001 FSAP recommendations was reviewed. The securities market supervision has

\footnotetext{
${ }^{2}$ The Bank of Spain dynamic provisioning model requires banks to make ex-ante general provisions at a provisioning rate linked to the average probability of default for different types of assets over the business cycle. It thus has the potential to slow excessive risk taking during cyclical upswings while providing a stock of general provisions that banks can draw on during cyclical downturns to cover losses when defaults on these assets are more likely to occur. This model is described in Bank of Spain Working Paper number 18, 2001, Credit Growth, Problem Loans and Credit Risk Provisioning in Spain, by Santiago Fernádez de Lis, Jorge Martinez Pagés and Jesùs Saurian.
} 
most enforcement powers. Amendments to the Securities Law will allow fines to be levied but only from January 2005, addressing an important remaining gap in these powers. However, supervisors still lack indemnity against legal actions.

\section{A single regulatory agency has been proposed to replace the lead supervisor}

approach. While this can be a successful model for supervision, there are a number of preconditions to assure success:

- $\quad$ The effectiveness of the model derives in part from the application of a consistent risk-focused approach across all the three areas of supervision. To capture these synergies, it might be desirable to focus resources initially on developing this capacity;

- $\quad$ The independence and adequate staffing of the integrated supervisor needs to be ensured for it to be effective and credible. This may require legislation to transfer crucial powers from the Ministry of Finance and $\mathrm{BoS}$ to the new agency;

- A comprehensive strategy for harmonizing regulatory powers and supervisory practices needs to be in place, which requires extensive planning beforehand;

- Implementation of this model has often proved disruptive and costly, which can result in a temporary decline in the effectiveness of supervision. To limit the risk to financial stability during the transition, the financial system should not be under stress or undergoing rapid change; and

- Effective mechanisms need to be in place for the timely provision of information on the condition of financial institutions by supervisors to the central bank for the latter to adequately perform its macro-prudential surveillance and crisis management roles.

34. Both the integrated supervisor and lead supervisor models can be successful models for supervision of financial conglomerates. The case for the former derives from the potential to more effectively use scarce supervisory resources and the scope for exploiting synergies. These benefits, however, depend on the structure of the conglomerates; for example, they might be limited or absent if one type of institution dominates the conglomerate (e.g., a large bank with a small insurance subsidiary). Another consideration is the risks during the transition.

\section{SuMMARY OF KeY RECOMMENDATIONS TO ADDRESS VULNERABILITIES}

- $\quad$ The current BoS monetary policy framework can effectively limit risks to exchange rate stability in the transition to EMU, but the BoS should develop the market infrastructure and gradually rely more on market intervention to prepare for EMU and strengthen the banking sector. 
- $\quad$ Banking supervision should strengthen its risk focus and ensure that pricing of risk and provisioning are appropriate and give consideration to how prudential tools, including provisioning policies, could be used to address risks. In this regard, the BoS could continue its discussions with Bank of Spain exploring the scope for adapting the dynamic provisioning model used in Spain to the Slovenian situation. These efforts may require an expansion of supervisory resources.

- Insurance supervision needs to strengthen the independence of the ISA, develop the technical skills of its staff (possibly making use of technical assistance), and provide senior staff with protection against legal actions for carrying out their duties. Also, responsibility for supervision of pensions must be clarified.

- In considering creation of a unified supervisory agency, the authorities need to assess whether the preconditions are in place and determine the most appropriate time to proceed taking into account the stresses on the financial system. 


\section{IMPLEMENTATION OF RECOMMENDATIONS FROM THE 2001 FSAP}

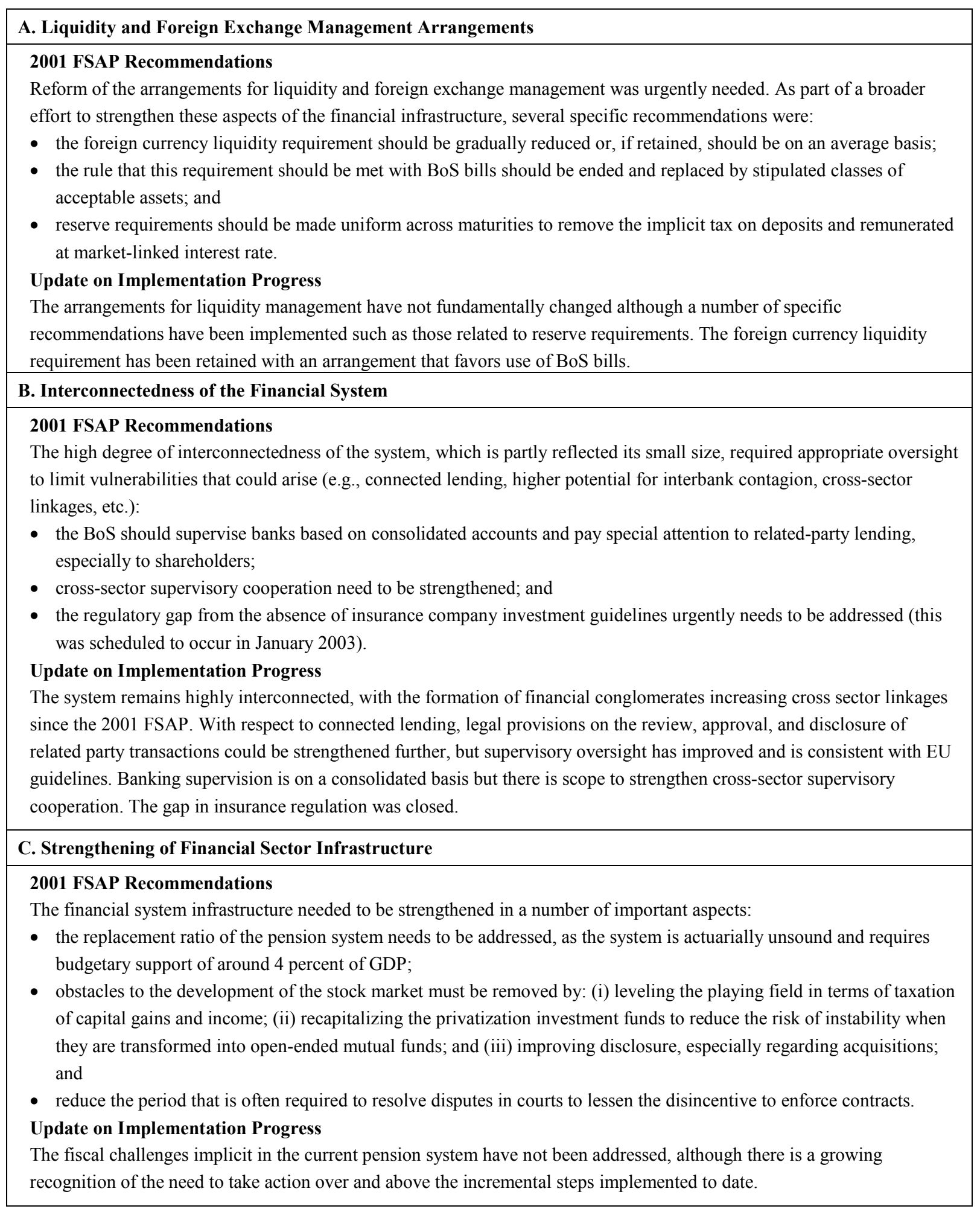




\section{SUMMARY ASSESSMENTS OF OBSERVANCE OF}

\section{FinanCIAL SECTOR STANDARDS AND CODES}

This appendix contains summary assessments of compliance with two core international standards and codes applicable to the financial sector: the Basel Core Principles for Effective Banking Supervision, and the IAIS Insurance Core Principle. The assessments help identify the extent to which the regulatory and supervisory frameworks are adequate to limit risks to financial stability and ensure effective functioning of the financial system. They also help identify priority areas for ongoing legislative revision and provide recommendations for improved financial regulation and supervision in various areas.

Detailed assessments of standards were undertaken based on a collegial peer review process as part of the FSAP update, with Marcel Maes (formerly Belgium Banking and Finance Commission) responsible for the Basel Core Principles and Rodney Lester (World Bank) responsible for the Insurance Core Principles.

The Slovenian authorities completed self-assessment questionnaires for these standards and codes, which with other information were made available to the peer group of experts. During the missions, the responses to the questionnaires and self-assessments were clarified and checked through subsequent discussion with the authorities and market participants.

Banking supervision was fully or largely compliant with a large number of core principles and had improved in some areas as reflected in a number of upgrades and very few downgrades relative to the 2001 core principles assessment. Nevertheless, there remain some areas where improvements are possible as detailed in the ROSC. The Insurance Core Principles were evaluated under the new methodology, which contributed to downgrades in a number of areas. The ROSC details a number of areas of low compliance that need to be addressed. An IOSCO reassessment was not conducted, but progress with regard to the 2001 FSAP recommendations was reviewed. Securities market supervision had a high degree of compliance with core principles in the 2001 assessment and the authorities have undertaken reforms to address the remaining areas of weakness identified in the assessment. For banking, insurance and securities market supervision, an important area where compliance needs to be strengthened relates to the lack indemnity for supervisors against legal action. 


\section{IIA. Basel Core Principles}

\section{Institutional and macro-prudential setting, market structure-overview}

35. As at June 30, 2003, the Slovenian banking system comprised 20 banks with total assets of SIT 4,832.6 billion, 2 savings banks with total assets of SIT 17.2 billion, and 14 savings and loan institutions with total assets of SIT 42.9 billion. ${ }^{3}$ The ratio of the aggregate total assets of the system to gross domestic product (GDP) is almost 80 percent. Supervision of these institutions was carried out by a staff of 54 employees (on June 30, 2003) in the Banking Supervision Department of the Bank of Slovenia.

36. Private and foreign ownership of the banking system has been increasing. In 2002, the sale of 39 percent of the government share in the biggest bank in Slovenia turned the government into a minority shareholder decreasing the share of state ownership in the overall banking system to around 20 percent (the country's second bank remains in majority state ownership). Meanwhile, foreign ownership of banking system equity more than doubled in 2002 to stand at 32.5 percent as at 31 December, and rose slightly further to 33.1 percent by the end of June 2003. At the end of 2002, of the 20 banks in operation, six were in majority foreign ownership (including one branch of a foreign bank), six more were wholly domestically owned, and the remaining eight were in majority domestic ownership. Of the last group, half had less than 1 percent foreign equity ownership.

37. The Slovenian banking system is quite concentrated. The market share of Slovenia's largest bank at the end of 2002, measured in terms of unconsolidated total assets, was 35.5 percent, or 39.3 percent including its three subsidiaries, roughly the same as a year earlier. The market share of the three largest banks was 55.4 percent, while the market share of the seven largest banks was 80.6 percent.

38. Banks performed better in 2002 than in past years, ending the financial year with pre-tax profits of SIT 46.0 billion. Only three banks posted a loss. The results were up by SIT 30.6 billion on 2001 before taking into account SIT 19.5 billion in losses by a major bank. The improved performance of banks in 2002 was partly due to changes brought in by the Slovenian Accounting Standards, which no longer require compulsory inflation-indexed revaluation of capital. Under the new rules, general capital revaluation is undertaken only if appreciation of the Euro against the Tolar in the preceding financial year exceeds 5.5 percent. In 2001 this appreciation was only 4.7 percent. With regard to performance in 2003, the mission was informed of growing pressure on the earning capacity due to the ongoing erosion of interest margins should significantly reduce bank profitability. Competition among banks is spreading and future access to full EU-membership will, among other things provide for a major increase in transparency and discipline in financial transactions in what is still to be considered as a highly interconnected environment. Banks will most certainly explore new

\footnotetext{
${ }^{3}$ The small savings and loan undertakings were established on the basis of the Savings and Loan Undertakings Act of 1990 and must comply fully with the Banking Act by February 20, 2004.
} 
strategies in order to compensate for these structural developments. Introduction of new fee generating financial products and higher risk taking in both balance and off-balance operations are likely responses. The supervisor should be prepared to face these new developments by enhancing his attention toward risk management issues.

39. BoS's supervision responsibilities have increased rapidly during the past few years. Prospective EU-membership has been a major driving force in the alignment of Slovenian banking regulation to that of the EU. This change has also triggered an extensive series of secondary legislation and recommendations aimed at improving the general approach to supervision. The BoS has to be commended for the substantial efforts undertaken to fulfill its additional supervisory responsibilities. However, serious concerns have to be raised as to the BoS's capacity to address successfully these new demands on supervision. Its salary scales are not adequate to attract and retain qualified staff leading to high turnover, especially regarding on-site examination staff. A structural change of the remuneration conditions should therefore be envisaged and given the highest priority in order to allow the BoS to organize and maintain an efficient and adequately staffed supervisory organization.

\section{Main findings}

40. Prudential regulations and powers are strong and the supervisory process, in general, is effective. This opinion is supported by the fact that twenty-seven core principles out of thirty were considered to be compliant or largely compliant.

41. There are a few issues that dominate. The first concerns the insufficient level of salaries compared to some other financial institutions as has already been mentioned. This structural weakness undermines the possibility to attract and maintain the appropriate professional skills needed to fulfill the expanding supervisory responsibilities. Appropriate changes in this area are long overdue.

42. The second issue is the need to introduce in the BA the requirement that banks lend to persons in a special relationship with the bank on an arm's-length basis. This is especially true given the still highly interconnected Slovenian society.

43. The third issue relates to consolidated supervision. Although banks have obligations to manage their risks on a group basis the BoS has not yet installed a mechanism allowing for a systematic evaluation of the risks from nonbanking elements in a banking group. It is strongly recommended to undertake efforts in this direction. 


\section{Principle-by-principle findings}

\section{Objectives, autonomy, powers, and resources (CP 1)}

44. Prudential regulations are sound and the BoS must be commended for the actions undertaken to enhance Slovenia's regulatory regime and its endeavor to meet international standards. However, the insufficiency of the salary schemes mentioned above will have to be addressed and the legal protection of the supervisory staff must be established.

\section{Licensing and structure (CPs 2-5)}

45. An effective licensing authority is in place supplemented by fair and equitable criteria to ensure a consistent approach is applied to permissible activities and ownership.

\section{Prudential regulations and requirements (CPs 6-15)}

46. The BoS requires licensed banks to maintain an amount of capital commensurate with the nature and scale of its risks. In practice all Slovenian banks are operating at capital adequacy levels in excess of required limits.

47. BoS supervision of banks addresses the general credit policy, loan approval procedure, i.e., the incurring of other types of exposure, the loan utilization and repayment procedure, etc. The scope of supervision includes, inter alia, the delimitation of competencies for loan approval and the degree of observance of loan approval procedures.

48. Regarding the approval by the board of supervision of large exposures it is recommended to address the modus operandi, the composition and quality of the supervisory board of the Slovenian banks. The prudential reporting of connected lending by banks needs to be enhanced and further enhancements to corporate governance in this area are warranted. This is especially true after the recent change in the definition of lending to persons in special relationship with banks.

49. The BoS has reviewed banks' adherence to the requirements imposed on financial institutions under laws and regulations governing anti-money laundering initiatives.

50. A BoS decree on the minimum extent and contents of auditors' report requires that a report on the compliance with risk control rules should be annexed to the auditor's report. This annex shall include at least a short description of individual types of risk, the auditors' opinion about the control of such risks and about the internal control system adequacy, identified deficiencies, explanations of compliance with the auditors' recommendations from previous years and the auditors' recommendations for an enhanced risk control. The object of the review is capital and capital requirements, credit risks, liquidity risks, interest risks, exchange risks, and general banking risks. The annex must also include a special report on the bank's internal audit activities. 


\section{Methods of ongoing supervision (CPs16-20)}

51. Off-site supervision relies, inter alia, on monitoring trends in banking operations based on accounting statements, prudential reporting and on a risk based analysis. On-site examinations are executed according to a predetermined schedule but their scope and frequency take account of the results of the off-site supervisory activities. However, the depth and frequency of supervision has been hampered by resource constrains and high staff turnover. In order to maximize efficiency additional synergies with the external auditors should be explored. ${ }^{4}$

52. Although banks are required to manage their risks on a group basis the BoS has not yet installed a mechanism allowing for a systematic evaluation of the risks from nonbanking elements in a banking group. It is strongly recommended to undertake efforts in this directions.

\section{Information requirements (CP 21)}

53. The BoS has established requirements for adequate accounting, records and internal control systems, and as part of its evaluation of risk management systems, determines whether each bank has satisfactory accounting processes and internal control systems. A bank's annual report and a banking group's consolidated annual report must be adequately audited by a certified public accountant.

\section{Formal powers of supervisors (CP 22)}

54. The BoS has the legal authority to restrict bank activity or a license or to revoke a bank license. The BoS also has, inter alia, powers to object to potential controllers or shareholders of banks, and to existing controllers or shareholders. In practice, the BoS seeks remedial action through informal means, principally through the use of moral suasion.

\section{Cross-border banking (CPs 23-25)}

55. The BoS has the legal means of supervising the activities of EU and foreign branches of the Slovenian banks. Global consolidated supervision is exercised in practice but only on a limited scale. In the future, supervisors will need additional training to carry out this type of tasks.

\footnotetext{
${ }^{4}$ The BoS tries to supplement its on-site supervision program with a series of meetings held with senior management of each bank. However, the primary target of bi-annual meetings is not yet fulfilled.
} 
Table 3. Recommended Action Plan to Improve Compliance of the Basel Core Principles

\begin{tabular}{|c|c|}
\hline Reference Principle & Recommended Action \\
\hline 1.2 Independence & $\begin{array}{l}\text { - the insufficiency of the salary schemes of } \\
\text { supervisory staff will have to be addressed in order } \\
\text { to be able to attract and maintain the appropriate } \\
\text { mix of skills. } \\
\text { - perform an in-depth analysis of the supervisory } \\
\text { objectives and the means needed to fulfill those } \\
\text { objectives. }\end{array}$ \\
\hline 1.5 Legal protection & $\begin{array}{l}\text { - appropriate legal protection of the supervisory staff } \\
\text { must be established }\end{array}$ \\
\hline 7. Credit Policies & $\begin{array}{l}\text { - revisit the role of the supervisory board in credit } \\
\text { decisions }\end{array}$ \\
\hline 9. Large Exposure Limits & $\begin{array}{l}\text { - enhance off- and on-site supervision of large } \\
\text { exposures }\end{array}$ \\
\hline 10. Connected Lending & $\begin{array}{l}\text { - enhance prudential reporting } \\
\text { - introduce legal requirement that loans to persons in } \\
\text { special relationship with the bank are extended at } \\
\text { arm's-length }\end{array}$ \\
\hline 12. Market Risks & - accelerate training of recently hired staff \\
\hline 13. Other Risks & - issue additional guidelines on operational risk \\
\hline 16. On-Site and Off-Site Supervision & $\begin{array}{l}\text { - explore additional synergies with the external } \\
\text { auditors in order to maximize efficiency }\end{array}$ \\
\hline 17. Bank Management Contact & $\begin{array}{l}\text { - fulfill the primary target of bi-annual meetings with } \\
\text { bank management }\end{array}$ \\
\hline 18. Off-Site Supervision & $\begin{array}{l}\text { - organize enhanced comprehensive analysis of } \\
\text { consolidated financial information }\end{array}$ \\
\hline 20. Consolidated Supervision & $\begin{array}{l}\text { - install mechanism for systematic evaluation of risks } \\
\text { from nonbanking elements in banking group }\end{array}$ \\
\hline 23. Globally Consolidated Supervision & $\begin{array}{l}\text { - increase scope and enhance practice of global } \\
\text { consolidated supervision }\end{array}$ \\
\hline
\end{tabular}




\section{IIB. IAIS Insurance Core Principles}

\section{General}

56. This is an assessment of the insurance regulatory and supervisory system in Slovenia. It has been carried out as part of a joint World Bank/ IMF FSAP and is a follow up to the Slovenian 2001 FSAP. It primarily examines the effectiveness of Slovenia' supervisory body, the Insurance Supervision Agency (ISA), a statutory body set up on June 1, 2000. Amendments to the law remain the responsibility of the Ministry of Finance. EU Directives generally supercede local law and the Insurance Law is accordingly due to be extensively amended in anticipation of Slovenia's entry into the EU on May 1st, 2004. This assessment was carried out between November 12 and November 21, 2003.

57. Key recommendations arising from the assessment reflect an increasingly complex environment, including a challenging investment environment, evolving accounting standards, the growth of the DC funded pensions pillars, the resolution of the ownership structures of two of the major insurers, the gradual emergence of financial conglomerates, developments in the health insurance sector and the ongoing evolution of EU minimum regulatory and supervisory requirements (including the likelihood of Solvency II and a new accounting standard for insurance contracts being introduced in the next 5 years).

58. Slovenian commerce is subject to a strict legal environment similar to the German Civil Code and a bicameral board structure operates in the corporate sector. Specialist law is allowed to override general laws and this has facilitated the development very specific and generally progressive insurance legislation.

\section{Institutional and macroprudential setting}

59. The Slovenian insurance market with a total written premiums in 2002 of SIT 266 billion (US\$1.4 billion) is small, reflecting the country's low population base of a little under 2 million people. However insurance penetration expressed in terms of premium as a percentage of GDP (5.1 percent including health) is easily the highest among the transitional Central European countries. Property and casualty insurance is still the largest direct insurance sector with 54.9 percent of premium income, down from 65 percent in 1997. Voluntary health insurance, written largely through a mutual is the second largest class, and life insurance accounts for 19.5 percent (17.5 percent in 1999). The sector's financial investments of SIT 422 billion as at June 30, 2003, amounted to a relatively low 8 percent of GDP (up from 6 percent in 1999) and is holding steady (before pensions assets are included) at 20 percent of household savings in banks.

60. Voluntary supplementary pensions may be written as life insurance, or through specialist pensions companies or pension mutual funds. The two latter sources of contractual savings accounted for assets of SIT 35.9 billion as at June 30, 2003 and are growing by approximately SIT 10 billion p.a. In addition a new civil service funded DC pension plan will soon be introduced and this should add approximately the same amount to the savings pool in its first full year of operation. As of August 31, 2003, there were more than 212,000 members 
in the new voluntary system, of which 84 percent had been written through life insurance or pensions companies. Three of four of the specialist pension providers now appear to be operating at above break even level.

61. There are 19 insurers based in Slovenia, including 2 reinsures, 1 specialist trade credit insurer and 1 mutual. The mutual is the market leading supplemental health insurer and is run on an actuarially funded basis. Of the 12 active "classic" insurers 10 write both life and nonlife classes, and there are four surviving pension companies. The industry association, the Slovene Insurance Association, acts as the Slovene Green Card Bureau and manages the guarantee fund for people injured by uninsured drivers.

62. The insurance industry appears to be operating profitably, after a further strengthening of provisions in 2001, although a few insurers remain financially vulnerable. However the industry is still relatively inefficient by international standards with premiums per employee closer to those in countries to the south rather than to the north and west. This will have to improve substantially for domestic insurers to remain competitive following EU accession, and the financial position of the local industry will require close monitoring in the next few years. .

63. Possible exposures for the insurance industry, aside from volatile Third Party Liability insurance and investment guarantees (see below), include the catastrophe potential of earthquake, and credit insurance. Slovenia has a major earthquake exposure (it had 19 earthquakes of intensity VII or greater in the last millennium) and there are good grounds for the carrying out a detailed loss potential study using modern modeling techniques.

64. Credit risk has been concentrated with Triglav over recent years. By some measures Triglav is now the default consumer credit provider for Slovenia (another insurer writes some of this business but allegedly has financial difficulties and is for sale). In particular Triglav appears to be - almost uniquely in the world — assuming 100 percent of the credit risk associated with most consumer loans (including overdrafts) issued by banks.

65. Supplementary DC voluntary pensions funds provided through insurers, pensions companies and pension mutual funds are required to provide a guaranteed monthly return based on 40 percent of the long term (greater than 1 year) real government bond rate over the previous two years, adjusted upwards by an inflation index (TOM). The pensions institutions have largely hedged this to date by investing in indexed bonds and bank deposits. Now that bonds are being issued in nominal terms, and interest rates are trending downwards, there appears to be a likelihood that there will be no secure assets available capable of matching the guarantee. This points to a need to modify the guarantee and possibly introduce new product structures offering higher long term returns (and increased short term asset value volatility). 


\section{Main findings}

66. There are two significant differences between this assessment and the 2001 assessment. The first is the employment of a new, substantially more demanding and searching methodology. The second is that ISA is now being assessed as a "going concern." Since 2000 the basic supervisory infrastructure has been built with 28 staff now in place, most of whom appear to be committed and able, but are still relatively inexperienced. In addition, an impressive body of regulations, operating procedures, and systems have been put in place.

67. During the period between assessments the ISA has conducted on and off site analyses for all insurers, and carried out inspections of the major insurers and those deemed to be at risk. In addition it has made numerous administrative "decisions," including requests that new capital be injected into some insurers. Despite these achievements, this follow up assessment has arrived at a somewhat less satisfactory conclusion than the first. In particular it has found issues related to the Agency's organization (and a lack of independence in particular), the interaction of insurer accounting and prudential management principles, and the supervision of derivative and related structured instrument exposures.

\section{Conditions for effective insurance supervision}

68. Macro management in Slovenia is effective and institutional settings are well developed. There is no reason that vibrant private insurance and pensions sectors could not be further developed.

\section{The supervisory system}

69. While the ISA is notionally independent the reality has proved to be somewhat different. In particular the responsible officer is the President of the Chamber of experts (rather than the Director), and there is no requirement that this person be a full time employee of the Agency. At the time of the assessment the Presidency changed hands and the new incumbent is a civil servant working in a government department. In addition it has become obvious that budget control rests with the government rather than the ISA Council.

70. Another concern is a lack of legal protection for the ISA responsible officers in the course of carrying out their normal activities in good faith.

\section{The supervised entity}

71. Criteria under this heading are generally observed or largely observed, and in most cases will be fully observed after the currently proposed amendments become law. The main concern under this heading involves governance. While Slovenia has strong audit and actuarial reporting requirements, there has been some evidence that supervisory boards have not been as strong as would ideally be required. In addition, given the territorial ambitions of its leading insurers, Slovenia may wish to take the lead in introducing a cooperation and information exchange protocol in the FRY countries. 


\section{Ongoing supervision}

72. Slovenia is still learning under the ongoing supervision heading, but has made a good start with a relatively active off and on site inspection regime (although there is some evidence that this has been, at least in part, audit rather than risk based). ISA management is well aware of market developments however the current legal structure does not allow ISA to intervene early enough. A regulatory ladder along the lines adopted in fully risk based regimes such as those in Canada and Mexico should be considered, given Slovenia's potential for advanced supervisory capabilities. Slovenia is well advanced in its preparation for group and conglomerate supervision, but given the relevant deadline (late 2004 for conglomerates) could possibly allocate more resources to this issue. In addition there is a need for a more coordinated supervisory approach given the emergence of three potential financial conglomerates and the current fragmentation of pensions supervision.

73. Notwithstanding constraints on early intervention ISA has been successful in enforcing a number of difficult decisions including changing managements and requiring increases in subscribed capital and reinsurance capital support.

\section{Prudential requirements}

74. Slovenia basically follows the EU prudential approach, which is now recognized as being inadequate if not supplemented with other requirements. The main line of defense in practice is the appointed actuary, who under the various regulations has to allow for the full balance sheet position of the insurer when setting provisions. Discussions with senior members, of what is a young profession, have satisfied the assessor that a pleasing degree of professional maturity is already emerging. However given its core role in Slovenia the local actuarial profession would benefit from an accelerated development program, supported by a senior advisor from a risk based jurisdiction with a long established actuarial profession.

75. Another concern is that there is a clear disconnect between the actuarial and accounting professions and this will need to be resolved, possibly through a formal liaison committee, if changes in accounting standards are not to threaten the prudential management of insurers. In this regard a recently introduced standard on the valuation of listed assets has had a potentially perverse impact, given that liability valuation has not changed in practice, relevant ISA guidelines notwithstanding.

76. The current Insurance Act is deficient with regard to derivatives and structured instruments and should be substantially strengthened 


\section{Markets and consumers}

77. The market conduct regime is relatively strong. However there is a need to provide ISA with greater specificity and powers regarding withdrawal of an intermediary's license, when the intermediary is a legal person. Relevant articles are included in the draft amendment law currently being prepared. In addition further regulation is required to ensure that insurers have procedures in place to ensure fair treatment of consumers. The industry itself is well advanced in this regard with the recent introduction of various claims resolution procedures and a related concordat.

\section{Anti-money laundering, combating the financing of terrorism}

78. The legal underpinnings necessary to deal with fraud and money laundering are in place in Slovenia. However there is need to strengthen administrative and supervisory procedures at the ISA level.

Table 5. Recommended Actions to Improve Observance of IAIS Insurance Core Principles

\begin{tabular}{|l|l|}
\hline \multicolumn{1}{|c|}{ Reference Principle } & \multicolumn{1}{|c|}{ Recommended Action } \\
\hline $\begin{array}{l}\text { Conditions for effective insurance } \\
\text { supervision }\end{array}$ & \\
\hline i.e., CP 1 & $\begin{array}{l}\text { The actuarial profession should undergo an accelerated development } \\
\text { program. An actuarial - accounting standard coordination capacity } \\
\text { should be established (ideally a formal liaison committee). }\end{array}$ \\
\hline The supervisory system & $\begin{array}{l}\text { The distribution of powers within ISA should be reassessed, with the } \\
\text { Director having day to day supervisory responsibilities, and policy } \\
\text { matters and important approvals staying with the Council of Experts. } \\
\text { Funding arrangements should ensure a greater degree of independence } \\
\text { at the level of the Council. Responsible officials within ISA should be } \\
\text { given legal protection where they perform their duties in good faith. }\end{array}$ \\
\hline i.e., CPs 2-5 & $\begin{array}{l}\text { The role of Supervisory boards should be made clearer and ideally } \\
\text { these governance mechanisms should be required to set up audit and } \\
\text { risk committees (particularly if above 5 members). Recent precedent in } \\
\text { Germany and Austria could provide arguments against any supposed } \\
\text { legal barriers to this reform. }\end{array}$ \\
\hline The supervised entity & $\begin{array}{l}\text { A risk based formal early intervention regime needs to be instituted } \\
\text { supported by relevant law and regulation. Increased resources should } \\
\text { be allocated to preparations for the financial conglomerate supervision } \\
\text { directive, which requires that a lead supervisor be nominated. In this } \\
\text { regard steps should be taken to intensify the existing coordination } \\
\text { between the three financial supervisors. }\end{array}$ \\
\hline i.e., CPs 6-10 & $\begin{array}{l}\text { Ongoing supervision } \\
\text { i.e., CPs 11-17 }\end{array}$ \\
\hline Prudential requirements & \\
\hline
\end{tabular}




\begin{tabular}{|c|c|}
\hline Reference Principle & Recommended Action \\
\hline i.e., CP 18-23 & $\begin{array}{l}\text { See comments above regarding strengthening the professional standing } \\
\text { of the actuarial profession and coordinating actuarial and accounting } \\
\text { standards and methodologies. Given the move to market valuation of } \\
\text { assets, liability valuation assumptions should be reviewed and balance } \\
\text { sheet resilience testing introduced (as a precursor to Solvency II). } \\
\text { Composites should be encouraged to separate into life and non life } \\
\text { insurers. The law should be amended to incorporate the derivatives and } \\
\text { structured instrument requirements of the relevant IAIS core principle. } \\
\text { Finally, high risk classes such as credit insurance should ideally be } \\
\text { written through appropriately capitalized, and separately licensed, } \\
\text { specialist insurers. }\end{array}$ \\
\hline \multicolumn{2}{|l|}{ Markets and consumers } \\
\hline i.e., CPs 24-27 & $\begin{array}{l}\text { The law needs to strengthen ISA's powers regarding withdrawal of } \\
\text { legal person intermediary licenses and imposition of insurer } \\
\text { responsibility for information exchange at the consumer interface. }\end{array}$ \\
\hline $\begin{array}{l}\text { Anti-money laundering, combating the } \\
\text { financing of terrorism }\end{array}$ & $\begin{array}{l}\text { The law is generally adequate but more implementation activity is } \\
\text { required at the supervisory level. }\end{array}$ \\
\hline i.e., CP 28 & \\
\hline
\end{tabular}

